\title{
Managed flooding can augment the benefits of natural flooding for native wetland vegetation
}

\author{
Alice Duong ${ }^{1 *}$, Joe Greet ${ }^{1}$, Christopher J Walsh ${ }^{1}$, Michael J Sammonds ${ }^{1}$ \\ ${ }^{1}$ School of Ecosystem and Forest Sciences, The University of Melbourne, Burnley, VIC 3121 \\ *Corresponding author
}

\section{Running head}

Managed flooding benefits native wetland vegetation

\author{
Authors and addresses: \\ Alice Duong \\ alice.duong@unimelb.edu.au \\ School of Ecosystem and Forest Sciences, The University of Melbourne, Burnley, VIC 3121 \\ Joe Greet \\ greetj@unimelb.edu.au \\ School of Ecosystem and Forest Sciences, The University of Melbourne, Burnley, VIC 3121
}

Christopher J Walsh

cwalsh@unimelb.edu.au

School of Ecosystem and Forest Sciences, The University of Melbourne, Burnley, VIC 3121

Michael J Sammonds

sm@unimelb.edu.au

School of Ecosystem and Forest Sciences, The University of Melbourne, Burnley, VIC 3121

\section{Author contributions:}

This is the author manuscript accepted for publication and has undergone full peer review but has not been through the copyediting, typesetting, pagination and proofreading process, which may lead to differences between this version and the Version of Record. Please cite this article as doi: $10.1111 /$ rec.12816

This article is protected by copyright. All rights reserved. 
$A D$, JG conceived of and designed the research; AD, JG performed the fieldwork; all authors analyzed the data, and wrote and edited the manuscript.

This article is protected by copyright. All rights reserved. 


\begin{abstract}
Managed flooding is increasingly being used to maintain and restore the ecological values of floodplain wetlands. However, evidence for its effectiveness is sometimes inconsistent and water available for environmental purposes often limited. We experimentally inundated a floodplain wetland (or 'billabong') in late spring by pumping water from its adjacent creek, aiming to promote the native wetland flora and suppress terrestrial exotics. Vegetation was surveyed before (spring) and after (late summer) the managed flood in the experimental billabong and in three control billabongs. Floodplain water levels were continuously monitored. Wet conditions caused two of the control billabongs to also flood, but to a lesser extent than the experimental billabong. We therefore assessed vegetation changes relative to flooding duration. With increasing flooding duration, the cover of wetland vegetation (amphibious and aquatic species) increased and the cover of terrestrial and exotic vegetation decreased, with these effects largest in the deliberately flooded billabong. Flooding durations $>20$ days generally resulted in increased cover of wetland plants and restricted the growth of terrestrial plants. Reinstatement of more appropriate flooding regimes can thus promote native wetland plants, while suppressing terrestrial exotic species. Our study also provides evidence for the use of modest water allocations to augment the benefits of natural flooding in the maintenance and restoration of native wetland plant communities.
\end{abstract}

\title{
Keywords
}

Managed flooding; Floodplain wetlands; Billabongs; Environmental watering; Environmental flows; Wetland restoration.

\section{Implications}

\section{Implications for practice}

- Reinstating more natural flooding regimes can promote native wetland plant communities, while concurrently suppressing terrestrial exotic species. 
- The effectiveness of modest environmental water allocations can be increased by augmenting natural floods, thus improving our ability to manage and restore wetland environments.

This article is protected by copyright. All rights reserved. 


\section{Introduction}

Wetlands are highly productive ecosystems that provide important ecological services including flood attenuation, carbon storage and biodiversity conservation (Zedler \& Kercher 2005). Despite this, they are among the most threatened ecosystems globally (Davidson 2014). The degradation of floodplain wetlands in particular, has largely been driven by the growing human demands for land and water (Van Asselen et al. 2013). Increasingly, managed flooding (or environmental watering) is being used to maintain or restore floodplain wetlands, but given competing demands for water, clearer evidence of its effectiveness is needed (King et al. 2010).

In Australia, floodplain wetlands are also known as 'billabongs', a term of Aboriginal origin (Wilde et al. 2005). Billabongs are highly dependent on variable flooding pulses from nearby creeks and rivers, with this lateral connectivity driving their physical and biological processes (Junk et al. 1989). In particular, flooding provides the hydrological disturbance that shapes billabong vegetation composition and structure (Reid et al. 2016).

Flooding imposes a strong selection pressure on plants, with plant species typically distributed along gradients from wet to dry according to their ability to tolerate or respond to flooding and drying (Blanch et al. 1999). However, flooding in many wetlands has been substantially reduced by human activities, e.g. through the construction of dams or levees (Poff et al. 1997; Kingsford 2000). Reduced flooding can result in near-permanently dry conditions that reduce the extent of amphibious species and favor terrestrial and exotic species (Catford et al. 2011). The proliferation of terrestrial and exotic species can reduce the biodiversity and ecosystem function of floodplain wetlands (Davis \& Froend 1999; Zedler \& Kercher 2005). While wetland restoration is generally agreed to depend on restoring appropriate hydrology (Poff et al. 1997; Yang et al. 2016), effective wetland restoration is often limited by our understanding of eco-hydrological relationships (Lake et al. 2007), with evidence for responses of wetland plant communities to water regime changes often inconsistent among studies (Webb et al. 2012; Thompson et al. 2017).

Managed flooding is a strategy that is increasingly being used to maintain and restore wetlands. However, the use of water for environmental purposes must have a solid scientific basis, due to competing demands for water (King et al. 2010). Modest environmental watering may have limited effect (Glenn et al. 2017), but the benefits derived from limited environmental water may potentially 
be increased by augmenting natural flow pulses (Reid \& Quinn 2004). Nonetheless, further research is required to determine the effectiveness of reinstating more natural flooding regimes for promoting native wetland plant communities (Catford et al. 2014; Greet et al. 2015).

These challenges are of concern at the Yellingbo Nature Conservation Reserve (YNCR) in southern Victoria, Australia, where levees and channels have been constructed to divert floodwaters away from adjacent farmland. YNCR supports floodplain wetlands of biological significance, including the largest remaining extent of the threatened 'Sedge-rich Eucalyptus camphora Swamp' community (Turner 2003). This threatened community provides important habitat for the critically endangered helmeted honeyeater (Lichenostomus melanops cassidix) and Leadbeater's possum (Gymnobelideus leadbeateri) (Pearce \& Minchin 2001; Harley et al. 2005). Hence, there is a strong impetus to restore and protect floodplain wetlands within the reserve.

Our study investigated the use of managed flooding to restore billabongs in YNCR. We introduced a small managed flood into one billabong in late spring and surveyed the vegetation of this billabong and three control billabongs before and after the managed flood. Increased inundation duration via managed flooding was predicted to promote the cover of native wetland vegetation and reduce the cover of terrestrial and exotic species.

\section{Methods}

\section{Study area}

For this study, we surveyed four billabongs in YNCR (Figure 1). The reserve comprises linear sections along several creeks including the Woori Yallock Creek and supports remnant riparian vegetation flanked by cleared agricultural land. 'Sedge-rich Eucalyptus camphora Swamp' community dominates the wettest areas of the reserve. This community has an open canopy of E. camphora (mountain swamp gum), in association with Melaleuca spp. and Leptospermum spp. shrub thickets, and a species-rich ground layer of rushes, sedges, grasses and forbs. In areas of past disturbance (e.g. clearing), weed species are often dominant, such as Phalaris arundinacea (reed canary-grass) and Ranunculus repens (creeping buttercup) (Turner 2003).

This article is protected by copyright. All rights reserved. 
This study focused on four billabongs within YNCR adjacent to the Woori Yallock Creek locally known as 'BOCA Swamp', 'McColls Swamp', 'Waterpoint Swamp' and 'Vermmalforts Swamp' (Figure 1). The billabongs are former anabranches or paleochannels of the Woori Yallock Creek, but have been long ( $>50$ years) disconnected from the creek by $\sim 1 \mathrm{~m}$ high levees and incision of the stream channel, which prevent overbank flows from reaching the billabongs except under major flood conditions (last known significant flooding was in 2011, 5 years prior to the study). In late winter to early spring, the billabongs experience some inundation in their lower parts from local run-off and sub-surface flows from their local catchments rather than from overbank flows. BOCA and McColls swamps have been mostly cleared of overstorey vegetation, but are bordered by areas of revegetation, while Waterpoint and Vermmalforts swamps contain remnant overstorey vegetation representative of 'Sedge-rich Eucalyptus camphora Swamp'. All sites support native understorey vegetation in varying levels of intactness.

\section{Study design}

We deliberately flooded one billabong, McColls, while the other three billabongs (BOCA, Vermmalforts and Waterpoint) served as controls (BACl design; Downes et al. 2002). At each site, a 40-m x 10-m plot was established perpendicular to the slope. Plots were fenced to exclude large herbivores, except at McColls swamp, which was entirely fenced (at a similar time) as part of a larger revegetation program. Within each plot, eight subplots $(5 \mathrm{~m} \times 5 \mathrm{~m})$ were established arranged in an alternating 'checkerboard' pattern. These were surveyed before (Oct-Nov 2016) and after (Jan-Feb 2017) the managed flood event at McColls to assess the response of the extant vegetation (Figure 2).

\section{Vegetation surveys}

The managed flood was timed to coincide with the Austral growing season, a period when plant biomass/cover could be expected to increase. We aimed to compare the differences in seasonal vegetation changes between the impact and control billabongs associated with flooding during this period of plant growth. For each survey, the vegetation within each subplot was surveyed using three randomly located $1-\mathrm{m}^{2}$ quadrats. Within each quadrat, all plants were identified to species level where possible and given a cover-abundance score based on a modified Braun-Blanquet coverabundance scale (Mueller-Dombois \& Ellenberg 1974). Cover intervals used were: 0-5\%, 5-25\%, 25$50 \%, 50-75 \%$ and $>75 \%$.

This article is protected by copyright. All rights reserved. 


\section{Hydrology}

A staff gauge and water-level logger were installed in the deepest part of each billabong, and water level data were downloaded and gauge readings recorded monthly. The elevation of each subplot relative to the staff gauge was surveyed at the corners of each subplot and averaged. Hydrographs were created from the water-level data and mean subplot elevations used to determine duration of inundation between the 'before' and 'after' surveys at the subplot level. 3.2 ML of water was pumped from the adjacent Woori Yallock creek into McColls swamp over three days in late November, raising water levels by $\sim 50 \mathrm{~cm}$ over $\sim 0.5$ ha. The managed flood extended inundation of the billabong by approximately two weeks.

\section{Data Analysis}

Taxa were identified to species level where possible and grouped according to wetland plant functional group (WPFG, constituting three classes: amphibious, damp terrestrial or terrestrial; Table 1) and origin (two classes: native or exotic; Walsh \& Stajsic 2007). Mean cover was calculated for each species in each subplot using cover-class mid-points, and summed to estimate mean cover of each WPFG and origin class.

We used non-metric multidimensional scaling (NMDS) ordination to visualize between-subplot similarity, and permutational multiple analysis of variance (PMANOVA) (Anderson 2001) and indicator species analyses (De Caceres \& Legendre 2009) to assess differences and changes in species composition among study sites grouping by site and survey timing ('before', 'after'). For both the ordination and PMANOVA, similarity matrices were created using subplot-level data, and calculated using the Bray-Curtis dissimilarity measure on untransformed data (binary transformation of data did not alter PMANOVA results).

We also assessed the effect of inundation duration on the change in cover of each WPFG and origin class between the 'before' and 'after' surveys using beta regression (Cribari-Neto \& Zeileis 2010). Due to the lack of flooding at one of the control billabongs, Waterpoint swamp, regression analyses to test the effect of inundation duration were conducted using only data from the other three billabongs: BOCA, McColls, and Vermmalforts. We modeled two predictors: inundation duration, and a random, categorical variable, site. The change in percentage cover between the two surveys was scaled to between 0.5 and 0.95 (to fall within the limits of $0-1$ of the beta distribution). All 
regression analyses were examined to ensure they met the assumptions of residual normality and homogeneity of variance. For regression analyses, the coefficients and $95 \%$ confidence intervals of effects of interest are reported: if the confidence interval did not span zero, the effect was considered to be significant. All analyses were conducted in R. All code and data used for this study are freely accessible (https://osf.io/TSY8U/).

\section{Results}

\section{Hydrology}

Following wetter-than-average winter conditions, all the subplots at the target billabong (McColls) and most of the subplots at two of the three control sites (BOCA and Vermmalforts) flooded prior to the 'before' survey and were still inundated at the time of the before survey (Figure 2). The environmental watering event at McColls swamp produced a second flood peak in late Novemberearly December that extended flooding for approximately two weeks for all subplots at that site (Figure 2A). Waterpoint swamp remained mostly dry apart from two minor flood peaks that briefly ( $<2$ days) inundated a few of the subplots (Figure 2D).

\section{Vegetation composition}

Eighty-eight plant species were recorded across the four sites, comprising 27 amphibious (including 4 aquatic species), 26 damp terrestrial and 35 terrestrial species, of which 55 were native (Table S1). Eleocharis sphacelata, Cyperus lucidus, Persicaria praetermissa, Austrocynoglossum latifolium, Lotus uliginosus* and Holcus lanatus* were the most abundant species recorded (N.B. asterisks indicate exotic taxa). Almost all species surveyed were herbaceous, except for some germinating tree and shrub seedlings (Acacia, Eucalyptus, and Melaleuca spp.) recorded at McColls swamp following the managed flood.

The composition of the vegetation communities differed among the four billabongs (Figure 3; P(Site) $<0.001)$. For instance, McColls swamp was associated with greater cover of the amphibious spikerush Eleocharis sphacelata, while Waterpoint swamp was associated with greater cover of the damp terrestrial forb Austrocynoglossum latifolia. Changes in vegetation composition between the 'before' and 'after' surveys differed among sites $(P($ Site $\times$ Before/After $)=0.001)$. The shift in species composition at McColls swamp was associated with the common amphibious forb, Persicaria

This article is protected by copyright. All rights reserved. 
praetermissa. Conversely, the shift in the species composition at BOCA and Waterpoint swamps was in the opposite direction, associated with the common terrestrial forb, Lotus uliginosus*, and the damp terrestrial grass, Holcus lanatus*, both exotic species. Changes in species composition at Vermmalforts were less clear.

Additionally, indicator species analysis showed that the native amphibious forb, Persicaria decipiens, was significantly associated with McColls, only after the managed flood $(P=0.005)$. Conversely, the terrestrial species Calystegia sepium and Senecio linearifolius were associated with BOCA and Waterpoint swamps, respectively, for the 'after' survey $(P<0.05)$ (see S2 for more detail).

\section{Water plant functional groups}

The cover of amphibious species increased, while the cover terrestrial and damp terrestrial species decreased, with increasing inundation duration (Figure 4, Figure 5). Notably, above average increases in the cover of amphibious species and decreases in the covers of terrestrial and damp terrestrial species were recorded at McColls swamp.

Across all sites, amphibious species cover increased and damp terrestrial and terrestrial species cover remained low in subplots that flooded for $>20$ days between the 'before' and 'after' surveys (Figure 6). Conversely, damp terrestrial and terrestrial species cover increased and amphibious species cover did not in subplots that flooded for $<20$ days. At McColls swamp, where all plots were inundated for $>20$ days, the 'after' cover of amphibious species was generally greater, and the damp terrestrial and terrestrial cover lower, than at the three control sites.

\section{Plant origin}

The 55 native species recorded were from a range of WPFGs: 22 were amphibious species, 15 were damp terrestrial species and 18 were terrestrial species. In contrast, only 5 of the 33 exotic species recorded were amphibious species, while 17 were terrestrial species and 11 were damp terrestrial species. Correspondingly, the cover of exotic species decreased following longer periods of inundation, while the change in cover of native species was variable (Figure 7, Figure 8). Again, above average increases in the cover of native species and decreases in exotic species were recorded at McColls swamp. 


\section{Discussion}

As predicted, we found increasing duration of inundation to be associated with increased cover of wetland plant species and decreased cover of terrestrial species. Furthermore, in our systems, exotics were mostly terrestrial species and were thus reduced by longer duration floods. Hence, managed flooding augmented the benefits of naturally occurring flooding for native wetland vegetation by further promoting wetland plant cover and reducing the cover the terrestrial and exotic plant species. Our findings are consistent with recommendations to reinstate appropriate flooding regimes for the restoration of native wetland plant communities.

The vegetation response we observed is consistent with previous studies showing that the differing tolerances of plants species to flooding determines their distribution in wetland environments (Blanch et al. 1999; van Eck et al. 2006). This was evident at all sites, with few terrestrial plants found in subplots that had been inundated for $>20$ days. In contrast, the cover of amphibious species increased with longer duration floods. Amphibious species have evolved traits allowing them to disperse, survive and reproduce in response to flooding (Lytle \& Poff 2004; Catford \& Jansson 2014).

Like previous studies conducted where most exotic species are maladapted to flooded environments, we found the cover of exotic species reduced with increasing flooding duration (Stokes et al. 2010; Catford et al. 2011). Our results support the contention that reintroducing more natural flooding regimes has the potential to limit the invasion of terrestrial exotic species, while concurrently promoting native wetland species (Catford et al. 2014).

\section{Management implications}

More natural flooding regimes are being re-established in wetlands globally in a number of ways: 'passively' by disrupting drainage infrastructure, breaching levees or dam walls, or constructing culverts; or 'actively' via environmental flow releases or managed flooding (De Steven et al. 2006). Regular provision of environmental water is likely to increase the ecosystem services and biodiversity of wetlands (Yang et al. 2016). However, the volume of available water for environmental purposes is often constrained by other human demands and this can result in smaller water volumes than natural flooding and limit their ecological impact (Glenn et al. 2017; Thompson et al. 2017). The practice of releasing water in conjunction with naturally occurring floods to increase 
their depth and duration and augment benefits for wetland plants is supported by our study (Reid \& Quinn 2004).

Our study also supports the use of environmental watering as a management tool to control exotic species. Prolonged inundation of areas dominated by terrestrial weeds will reduce the standing biomass and may allow native species to establish (Greet et al. 2015). While terrestrial exotic species, particularly ruderal species, are likely to emerge between flooding events, regular inundation is likely to prevent them from dominating (Stokes et al. 2010).

Because our study included only one impact site, observed differences in responses between impact and control sites may be confounded. Indeed, the positive response we observed in part depended on extant native wetland vegetation (Siebentritt et al. 2004; Dawson et al. 2017). However, all sites supported some native wetland vegetation, and the impact site was formerly cleared and closer to cleared areas than two of our (not previously cleared) control sites. We consider longer inundation periods at the impact site to be the most likely cause of the increase of wetland flora and reduction of terrestrial flora at the deliberately flooded site. Nonetheless, further investigation, ideally with field-based experiments such as ours, is warranted (King et al. 2010).

Our study suggests that reinstating more natural flooding regimes can promote native wetland plant communities and reduce the prevalence of terrestrial exotic species, and that effects of modest environmental water allocations can be increased by augmenting natural floods, improving our ability to manage and restore wetland environments.

\section{Acknowledgments}

We thank Miles Stewart-Howie, the Yellingbo Ranger, without whom the study would not have been possible. Thanks also to: Friends of the Helmeted Honeyeater for providing the plants and advice; and Elise King, Sarah Moser, Ying Quek, Rob Dabal and Brian Duong for field assistance. This study was supported by: funding from Melbourne Water (MW) through the Melbourne Water ResearchPractice Partnership; and the Australian Research Council Linkage program (LP150100682) with MW, Parks Victoria, Zoos Victoria, and Greening Australia.

This article is protected by copyright. All rights reserved. 


\section{Literature cited}

Anderson M (2001) A new method for non-parametric multivariate analysis of variance. Austral Ecology 26:32-46

Blanch SJ, Ganf GG, Walker KF (1999) Tolerance of riverine plants to flooding and exposure indicated by water regime. Regulated Rivers-Research \& Management 15:43-62

Brock MA, Casanova MT (1997) Plant life at the edge of wetlands: ecological responses to wetting and drying patterns In: Klomp $\mathrm{N}$ and Lunt I, (eds) Frontiers in ecology: building the links. Elsevier Science, Oxford, UK

Casanova MT, Brock MA (2000) How do depth, duration and frequency of flooding influence the establishment of wetland plant communities? Plant Ecology 147:237-250

Catford JA, Downes BJ, Gippel CJ, Vesk PA (2011) Flow regulation reduces native plant cover and facilitates exotic invasion in riparian wetlands. Journal of Applied Ecology 48:432-442

Catford JA, Jansson R (2014) Drowned, buried and carried away: effects of plant traits on the distribution of native and alien species in riparian ecosystems. New Phytologist 204:19-36

Catford JA, Morris WK, Vesk PA, Gippel CJ, Downes BJ (2014) Species and environmental characteristics point to flow regulation and drought as drivers of riparian plant invasion. Diversity and Distributions 20:1084-1096

Cribari-Neto F, Zeileis A (2010) Beta regression in R. Journal of Statistical Software 42:1-24

Davidson NC (2014) How much wetland has the world lost? Long-term and recent trends in global wetland area. Marine \& Freshwater Research 65:934-941

Davis JA, Froend R (1999) Loss and degradation of wetlands in southwestern Australia: underlying causes, consequences and solutions. Wetlands Ecology and Management 7:13-23

Dawson SK, Kingsford RT, Berney P, Keith DA, Hemmings FA, Warton DI, Waters C, Catford JA (2017) Frequent inundation helps counteract land use impacts on wetland propagule banks. Applied Vegetation Science 20:459-467

De Caceres M, Legendre P (2009) Associations between species and groups of sites: indices and statistical inference. Ecology 90:3566-3574

This article is protected by copyright. All rights reserved. 
De Steven D, Sharitz RR, Singer JH, Barton CD (2006) Testing a passive revegetation approach for restoring coastal plain depression wetlands. Restoration Ecology 14:452-460

Downes BJ, Barmuta LA, Fairweather PG, Faith DP, Keough MJ, Lake PS, Mapstone BD, Quinn GP. (2002) Monitoring Ecological Impacts: Concepts and Practice in Flowing Waters. Cambridge University Press, Cambridge, UK

Glenn EP, Nagler PL, Shafroth PB, Jarchow CJ (2017) Effectiveness of environmental flows for riparian restoration in arid regions: a tale of four rivers. Ecological Engineering 106:695-703

Greet J, Webb JA, Cousens RD (2015) Floods reduce the prevalence of exotic plant species within the riparian zone: evidence from natural floods. Applied Vegetation Science 18:503-512

Harley DKP, Worley MA, Harley TK (2005) The distribution and abundance of Leadbeater's Possum Gymnobelideus leadbeateri in lowland swamp forest at Yellingbo Nature Conservation Reserve. Australian Mammalogy 27:7-15

Junk WJ, Bayley PB, Sparks RE (1989) The flood pulse concept in river-floodplain systems. Pages 110127 Proceedings of the International Large River Symposium Can. Spec. Publ. Fish. Aquat. Sci King AJ, Ward KA, O'connor P, Green D, Tonkin Z, Mahoney J (2010) Adaptive management of an environmental watering event to enhance native fish spawning and recruitment. Freshwater Biology 55:17-31

Kingsford RT (2000) Ecological impacts of dams, water diversions and river management on floodplain wetlands in Australia. Austral Ecology 25:109-127

Lake PS, Bond N, Reich P (2007) Linking ecological theory with stream restoration. Freshwater Biology 52:597-615

Lytle DA, Poff NL (2004) Adaptation to natural flow regimes. Trends in Ecology \& Evolution 19:94-100 Mueller-Dombois D, Ellenberg H. (1974) Aims and Methods in Vegetation Ecology. John Wiley and Sons, New York, US

Pearce J, Minchin PR (2001) Vegetation of the Yellingbo Nature Conservation Reserve and its relationship to the distribution of the Helmeted Honeyeater, Bell Miner and White-eared Honeyeater. Wildlife Research 28:41-52

This article is protected by copyright. All rights reserved. 
Poff NL, Allan JD, Bain MB, Karr JR, Prestegaard KL, Richter BD, Sparks RE, Stromberg JC (1997) The natural flow regime. Bioscience 47:769-784

Reid MA, Quinn GP (2004) Hydrologic regime and macrophyte assemblages in temporary floodplain wetlands: implications for detecting responses to environmental water allocations. Wetlands 24:586599

Reid MA, Reid MC, Thoms MC (2016) Ecological significance of hydrological connectivity for wetland plant communities on a dryland floodplain river, Maclntyre River, Australia. Aquatic Sciences 78:139158

Siebentritt MA, Ganf GG, Walker KF (2004) Effects of an enhanced flood on riparian plants of the River Murray, South Australia. River Research and Applications 20:765-774

Stokes K, Ward K, Colloff M (2010) Alterations in flood frequency increase exotic and native species richness of understorey vegetation in a temperate floodplain eucalypt forest. Plant Ecology 211:219233

Thompson RM, King AJ, Kingsford RM, Mac Nally R, Poff NL (2017) Legacies, lags and long-term trends: Effective flow restoration in a changed and changing world. Freshwater Biology:DOI: 10.1111/fwb.13029

Turner V. (2003) Action Statement Sedge-rich Eucalyptus camphora Swamp. Report by Arthur Rylah Institute for the Department of Sustainability and Environment, Melbourne, Australia Van Asselen S, Verburg PH, Vermaat JE, Janse JH (2013) Drivers of wetland conversion: a global meta-analysis. PloS one 8:1-13

Van Eck W, Lenssen JPM, Van De Steeg HM, Blom C, De Kroon H (2006) Seasonal dependent effects of flooding on plant species survival and zonation: a comparative study of 10 terrestrial grassland species. Hydrobiologia 565:59-69

Walsh NG, Stajsic V. (2007) A Census of the vascular plants of Victoria Royal Botanic Gardens, Melbourne, Australia

Webb JA, Wallis EM, Stewardson MJ (2012) A systematic review of published evidence linking wetland plants to water regime components. Aquatic Botany 103:1-14

This article is protected by copyright. All rights reserved. 
Wilde WH, Hooton J, Andrews B. (2005) The Oxford Companion to Australian Literature. Oxford University Press,

Yang W, Sun T, Yang Z (2016) Does the implementation of environmental flows improve wetland ecosystem services and biodiversity? A literature review. Restoration Ecology 24:731-742

Zedler JB, Kercher S (2005) Wetland resources: status, trends, ecosystem services, and restorability. Annual Review of Environment and Resources 30:39-74

This article is protected by copyright. All rights reserved. 
Table 1. Wetland plant functional groups (sensu Brock and Casanova 1997; 2000) used to group plants to assess responses to flooding duration.

\section{Functional group Criteria}

Amphibious

(includes both

amphibious and

aquatic species)

Damp terrestrial

Terrestrial
Species that germinate in damp or flooded conditions, grow or tolerate variation in water-level, and can grow with their basal portions under water and reproduce out of water (amphibious); species that can germinate, grow and reproduce under water (aquatic).

Species that germinate, grow and reproduce on damp soil.

Species that germinate, grow and reproduce where there's no surface water and the water table is below the soil surface.

This article is protected by copyright. All rights reserved. 




Figure 1. Locations of four study sites within Yellingbo Nature Conservation Reserve. Light grey area indicates the Yellingbo NCR, dark grey areas indicate the study sites (first letter indicates site, second letter indicates whether it was an impact, I, or control, C, site), black lines indicates streams, grey lines indicate roads. 

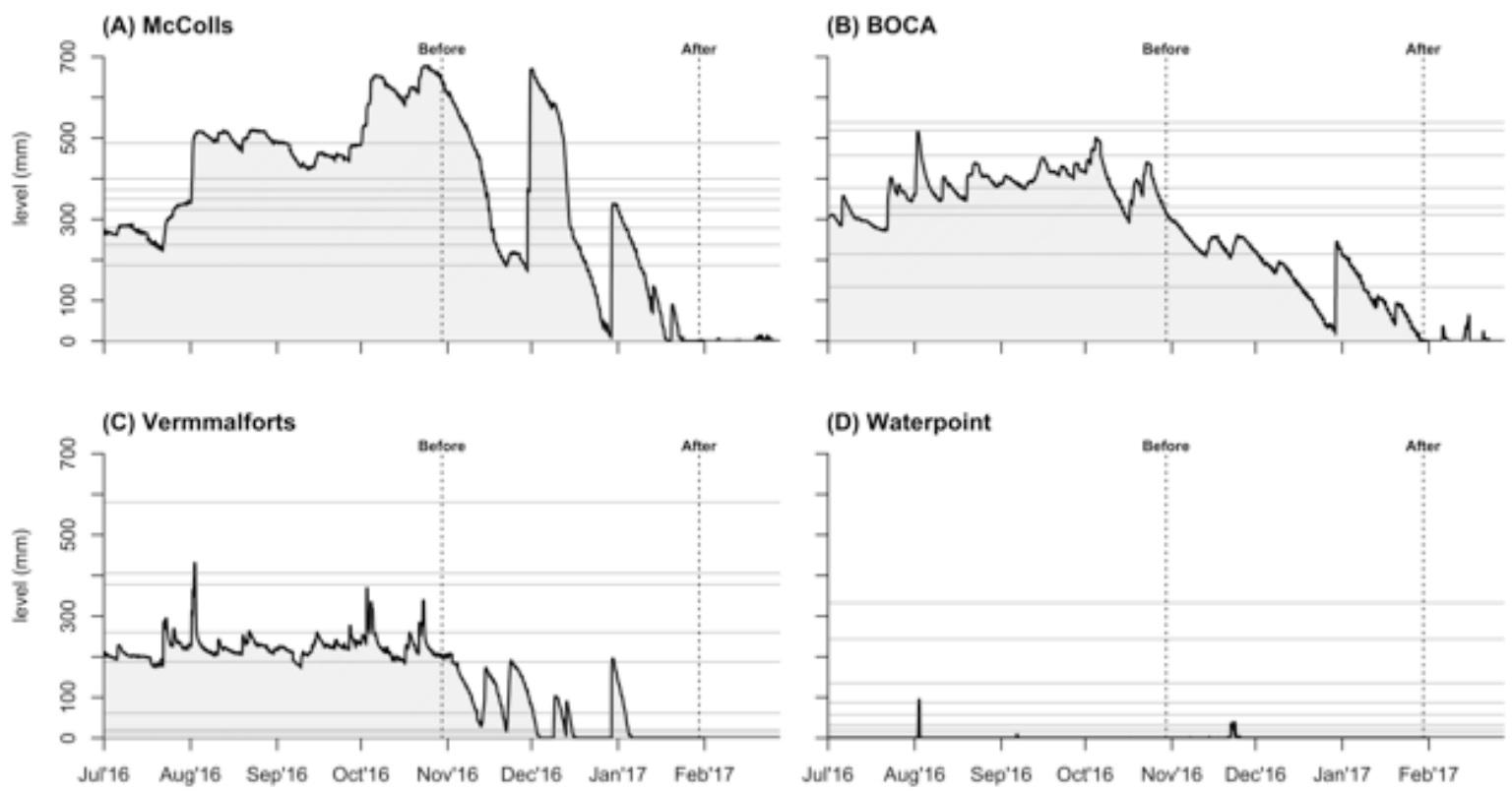

Figure 2. Hydrographs for the four study sites, the horizontal grey lines indicate the elevations of the subplots at each site relative to recorded water levels, and the grey shading indicates the period of inundation for each subplot. Approximate times of the 'before' and 'after' surveys are indicated. The managed flood at McColls is evident between these survey dates. 


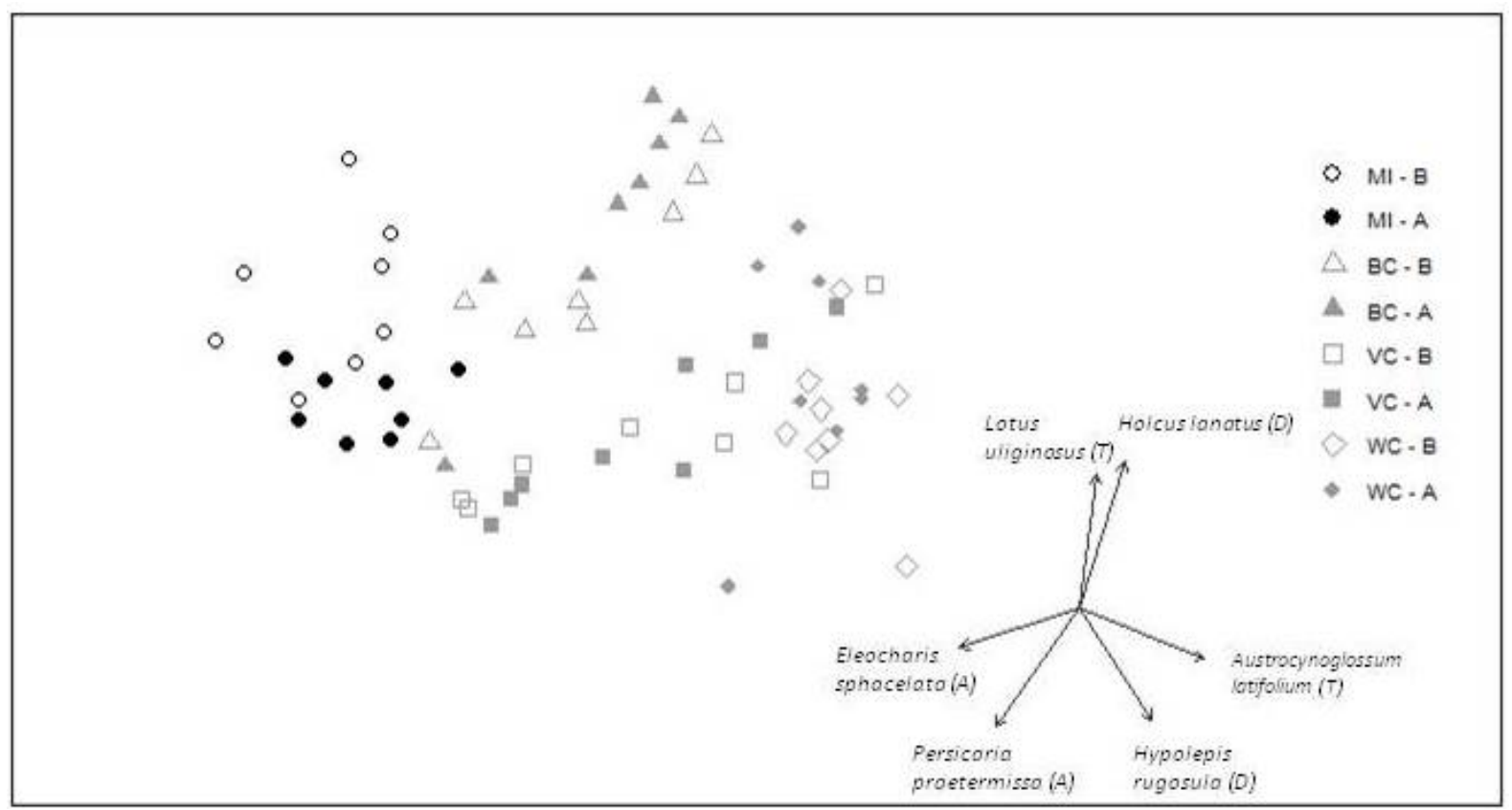

Figure 3. NMDS ordination of species composition in subplots of the four study sites for the 'before' (- B) and 'after' (- A) surveys. Site codes: $\mathrm{MI}=$ McColls; BC = BOCA; VC = Vermmalforts; WC = Waterpoint; first letter indicates site, second letter indicates whether it was an impact, I, or control, $C$, site. Species vectors correlated best $(P<0.001$ and Pearson's $R>0.3)$ with the ordination are shown, with their WPFG indicated in parentheses ( $A=$ amphibious; $D=$ damp terrestrial; $T$ = terrestrial). 
(A) Amphibious species

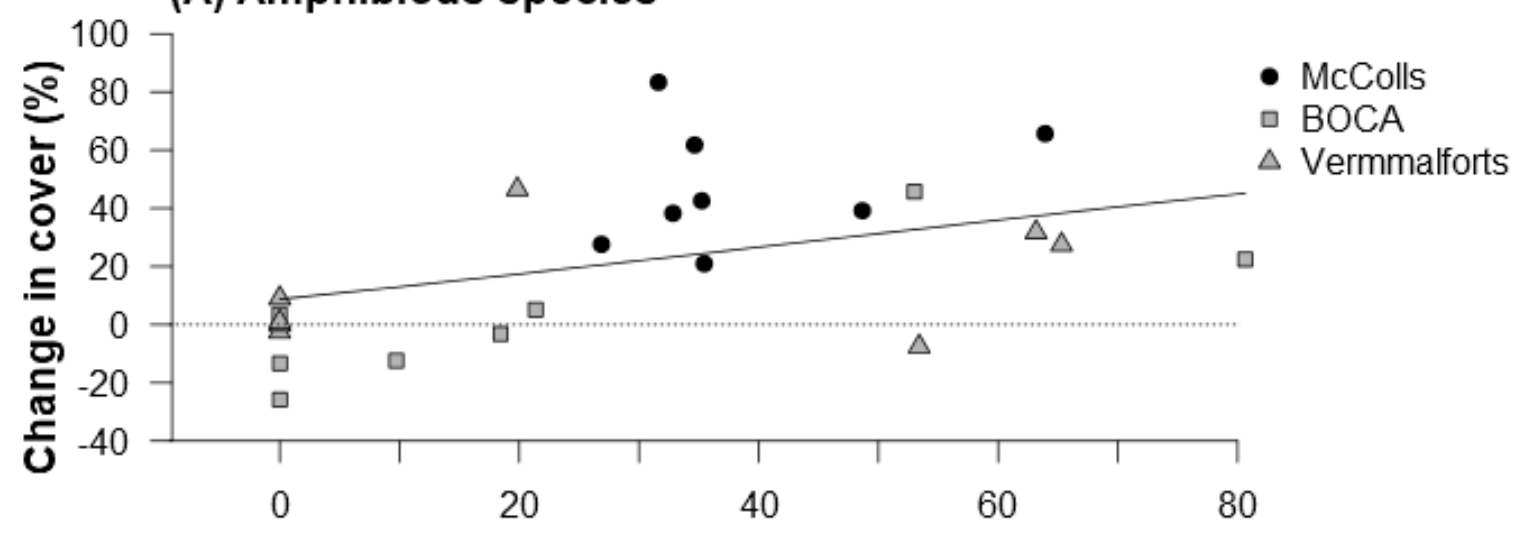

(B) Damp terrestrial species

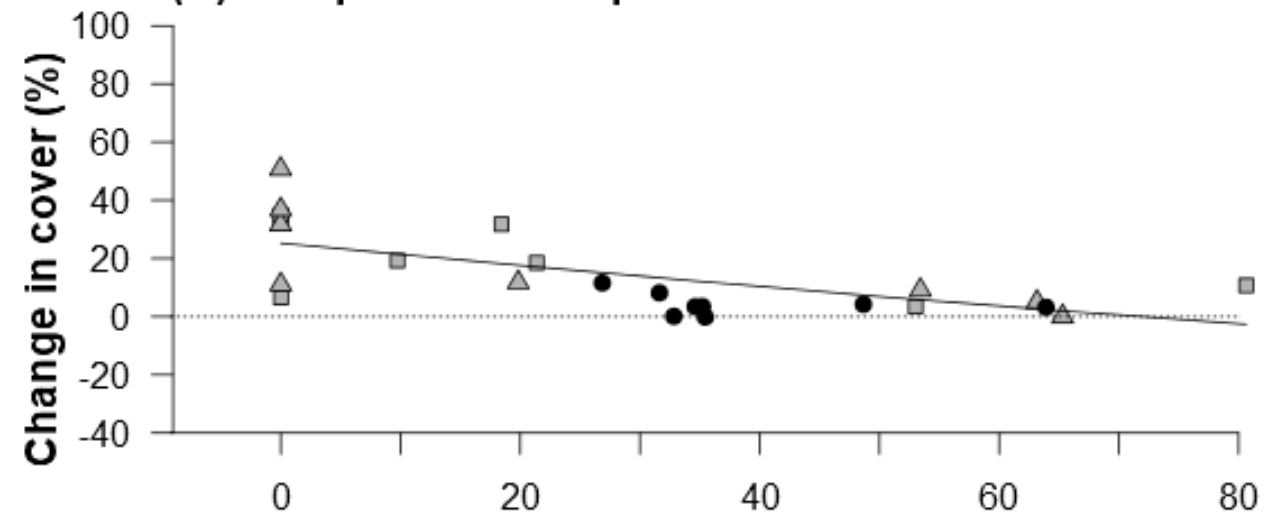

(C) Terrestrial species

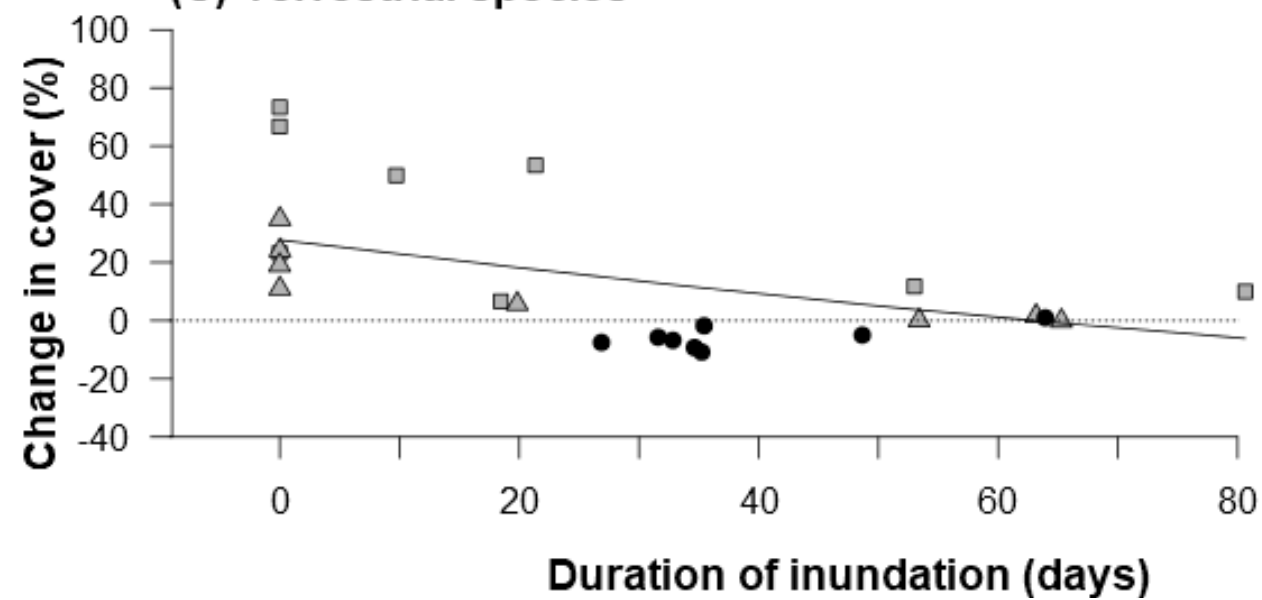

Figure 4. Change in percentage cover of (A) amphibious, (B) damp terrestrial and (C) terrestrial species at the deliberately flood billabong (McColls) and the two control billabongs (BOCA and Vermmalforts) that were 
variably flooded between the 'before' and 'after' surveys against duration of inundation. For each plot the line of best fit from the linear model is shown; estimated coefficients and confidence intervals of effects are presented in Figure 5.

This article is protected by copyright. All rights reserved. 


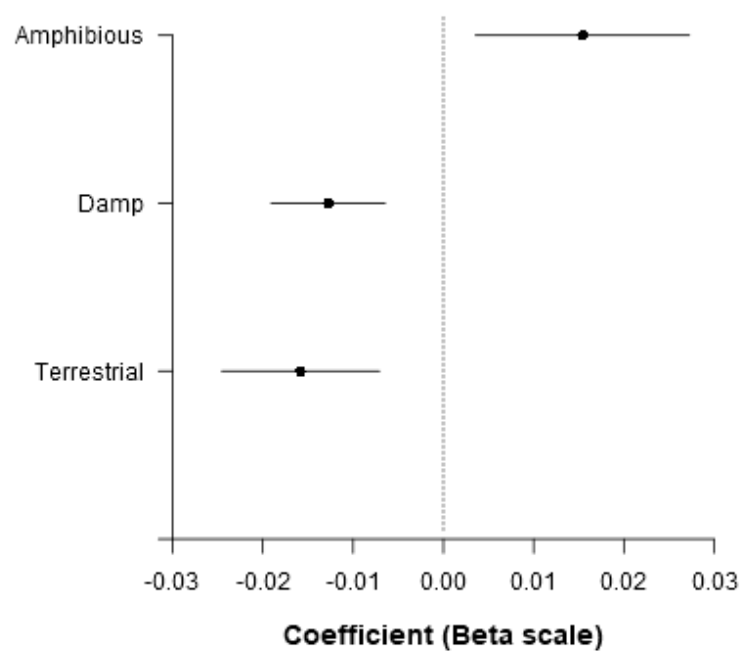

Figure 5. Coefficients and $95 \%$ confidence intervals from regression analysis of the effect of inundation duration on the change in cover of amphibious, damp terrestrial, and terrestrial species.

This article is protected by copyright. All rights reserved. 


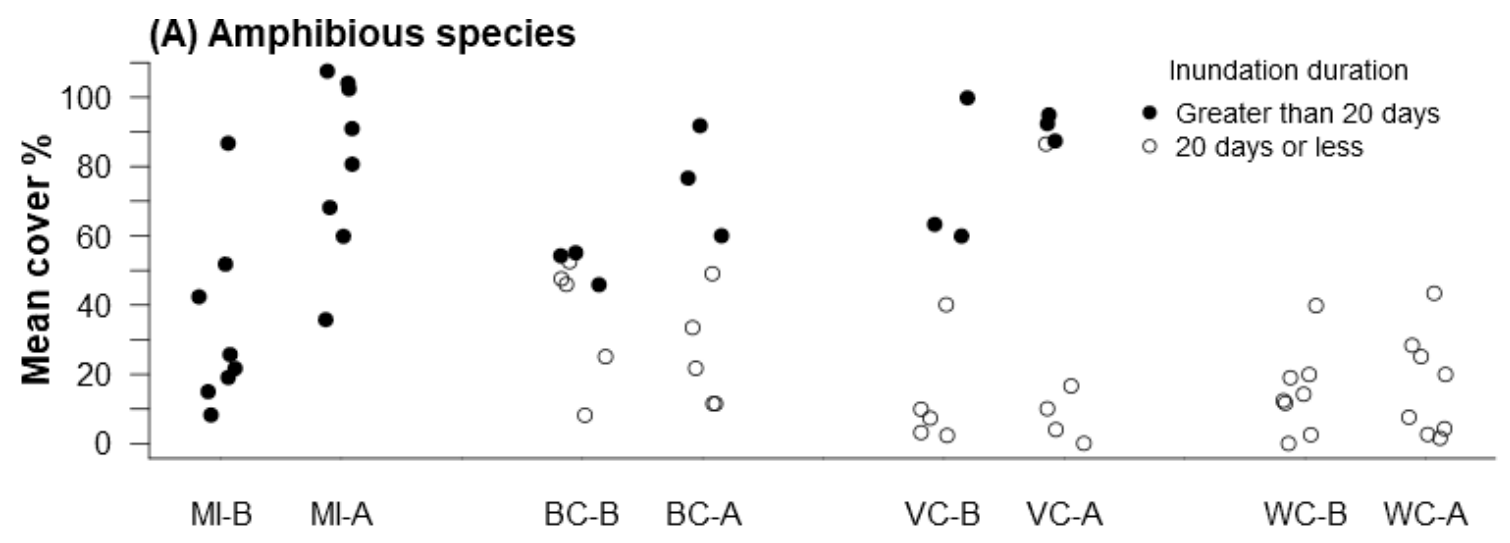

(B) Damp terrestrial species

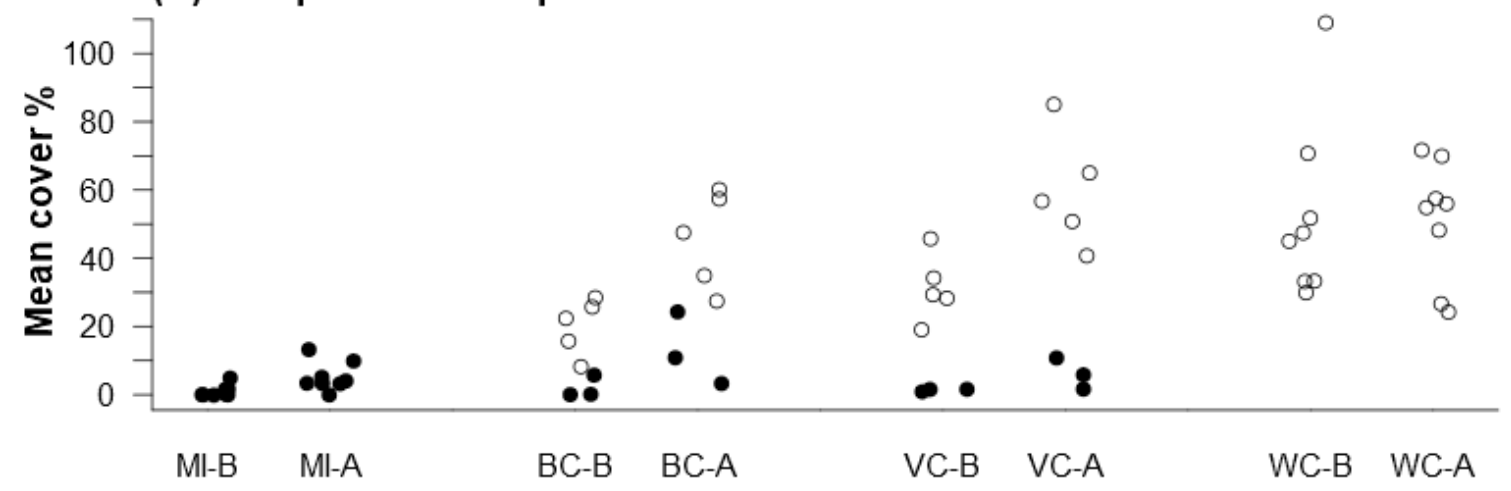

(C) Terrestrial species

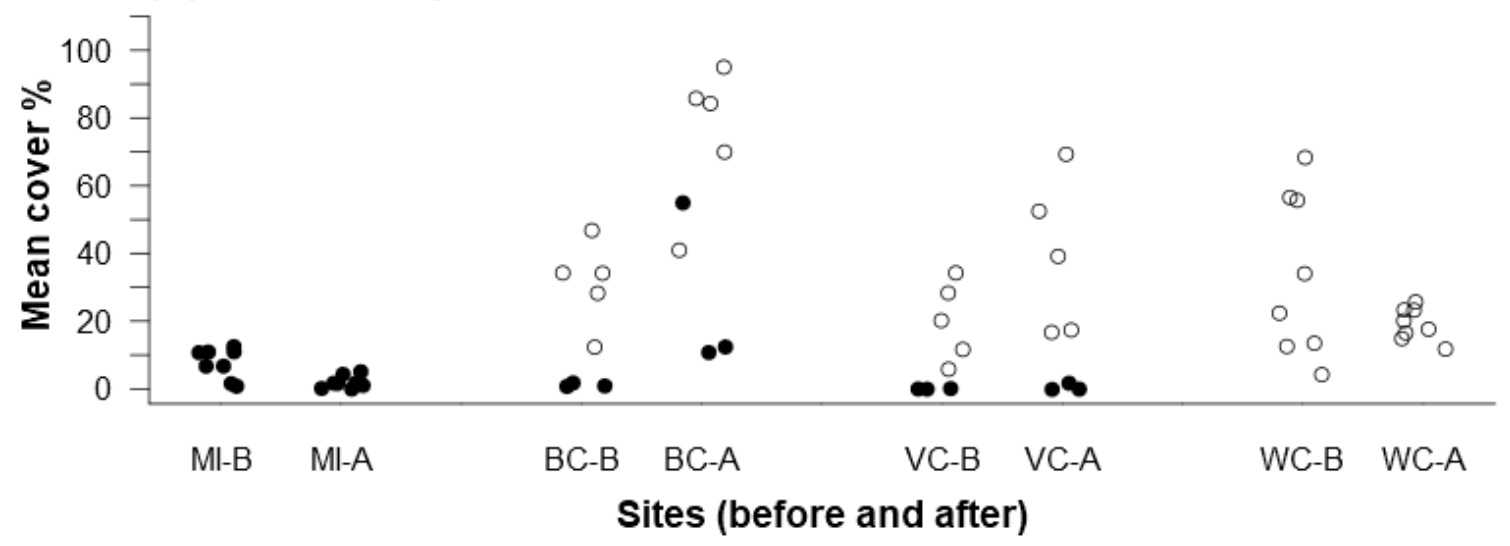

Figure 6. Mean cover of (A) amphibious, (B) damp terrestrial, and (C) terrestrial species for the 'before' and 'after' surveys for the four billabong sites (e.g. MI-B, McColls, 'before' survey). Symbols represent data at subplot level with black filled circles indicating subplots inundated for $>20$ days between surveys and unfilled circles indicating subplots inundated for $<\mathbf{2 0}$ days between surveys. Mean cover values are randomly jittered to reveal overlapping values. 
(A) Native Species

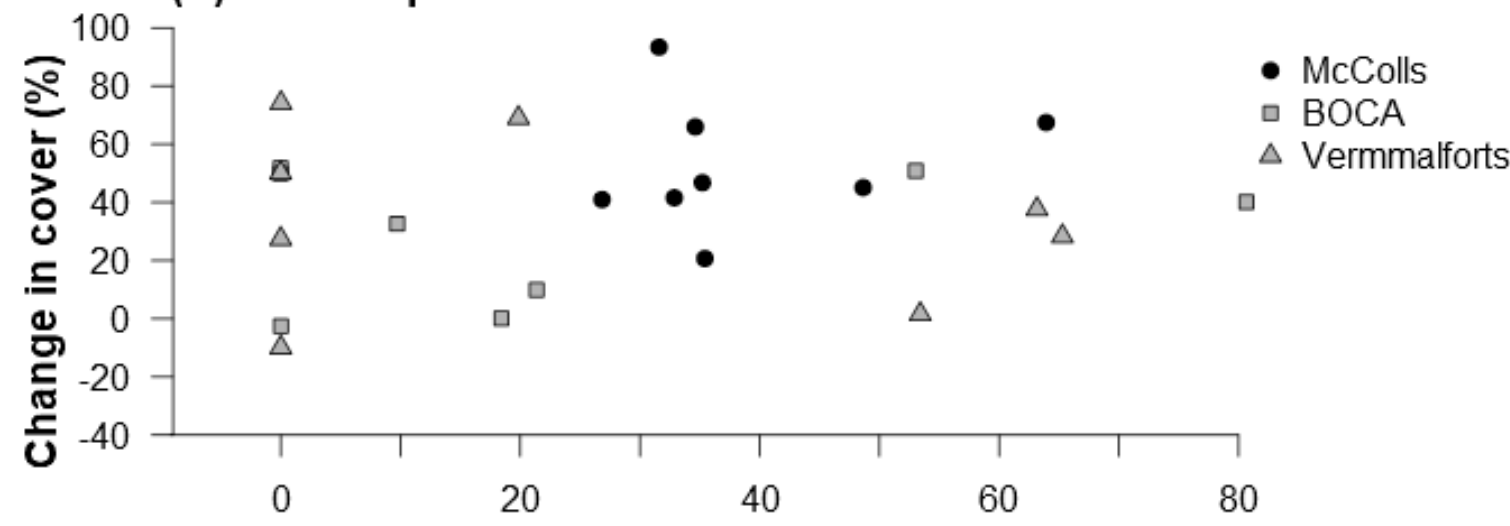

(B) Exotic Species

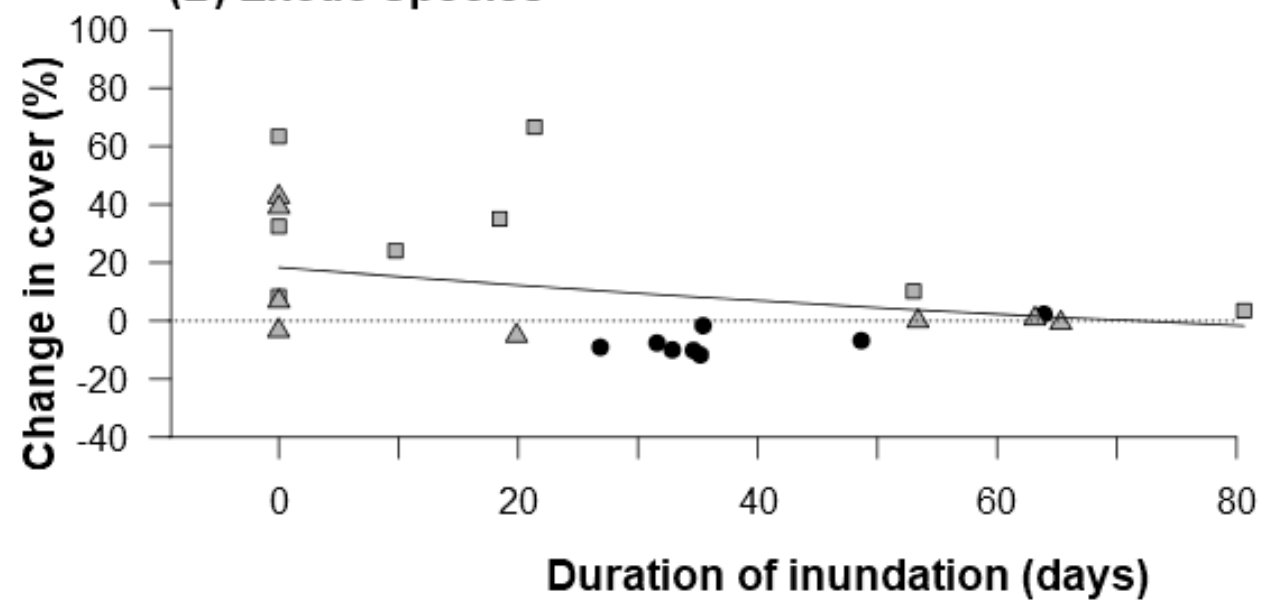

Figure 7. Change in percentage cover of (A) native and (B) exotic species at the deliberately flooded billabong (McColls) and the two control billabongs (BOCA and Vermmalforts) between the 'before' and 'after' surveys against duration of inundation. For exotic species, the line of best fit from the linear model is shown (the effect of duration of inundation on change in cover of native species was not significant); estimated coefficients and confidence intervals of effects are presented in Figure 8. 


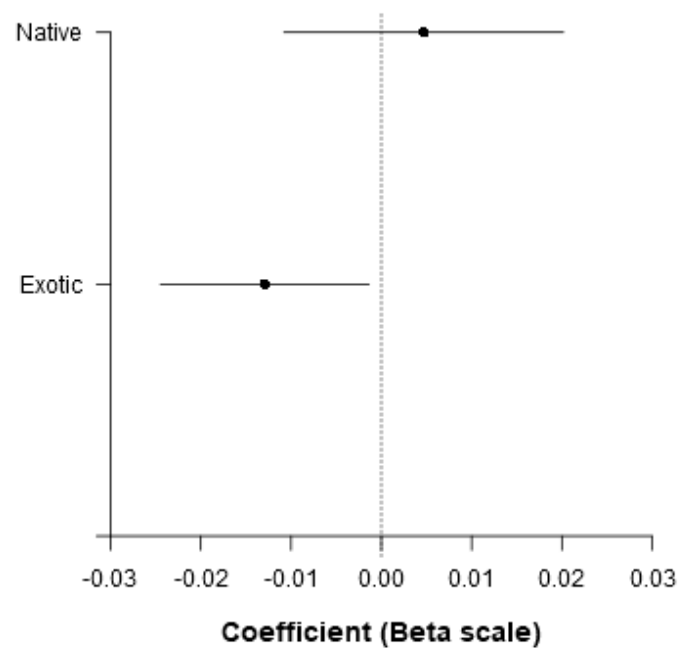

Figure 8. Coefficients and $95 \%$ confidence intervals from regression analysis of the effect of inundation duration on the change in cover of native and exotic species.

This article is protected by copyright. All rights reserved. 
Table S1. Summary of plant species recorded in either the 'before' or 'after' surveys. Species characteristics presented are: water plant functional group (A - amphibious, D - damp terrestrial or T - terrestrial); origin (native or exotic); and average percentage cover recorded in either the before or after survey averaged across all subplots and sites.

\begin{tabular}{|c|c|c|c|c|}
\hline Species & Functional group & Origin & $\begin{array}{r}\text { Average cover } \\
\text { before survey (\%) }\end{array}$ & $\begin{array}{r}\text { Average cover } \\
\text { after survey (\%) }\end{array}$ \\
\hline Acacia melanoxylon & $\mathrm{T}$ & native & 0.00 & 2.50 \\
\hline Acaena novae-zelandiae & $\mathrm{T}$ & native & 15.28 & 5.80 \\
\hline Acacia sp. & $\mathrm{T}$ & native & 0.00 & 2.50 \\
\hline Adiantum aethiopicum & $\mathrm{D}$ & native & 15.00 & 0.00 \\
\hline Agrostis stolonifera & $\mathrm{D}$ & exotic & 0.00 & 8.75 \\
\hline Alisma plantago-aquatica & $A$ & native & 2.50 & 6.67 \\
\hline Alternanthera denticulata & $\mathrm{D}$ & native & 0.00 & 2.50 \\
\hline Anthoxanthum odoratum & $\mathrm{T}$ & exotic & 6.07 & 2.50 \\
\hline Austrocynoglossum latifolium & $\mathrm{D}$ & native & 18.50 & 26.94 \\
\hline Azolla pinnata & $A$ & native & 2.50 & 10.00 \\
\hline Blechnum nudum & $\mathrm{D}$ & native & 18.33 & 2.50 \\
\hline Calystegia sepium & $\mathrm{T}$ & native & 2.50 & 27.13 \\
\hline Callitriche stagnalis & $A$ & exotic & 2.50 & 2.50 \\
\hline Carex appressa & $A$ & native & 19.17 & 18.68 \\
\hline Carex fascicularis & $A$ & native & 0.00 & 2.50 \\
\hline Carex gaudichaudiana & $A$ & native & 8.82 & 15.91 \\
\hline Cardamine hirsuta & $\mathrm{D}$ & exotic & 2.50 & 2.50 \\
\hline Carex sp. & $A$ & native & 0.00 & 2.50 \\
\hline Centella cordifolia & $A$ & native & 2.50 & 2.50 \\
\hline Cerastium glomeratum & $\mathrm{T}$ & exotic & 2.50 & 2.50 \\
\hline Cerastium vulgare & $\mathrm{T}$ & exotic & 2.50 & 0.00 \\
\hline Cirsium vulgare & $\mathrm{T}$ & exotic & 3.24 & 5.63 \\
\hline Coprosma quadrifida & $\mathrm{T}$ & native & 6.67 & 2.50 \\
\hline Crassula helmsii & $A$ & native & 8.75 & 8.33 \\
\hline Cyperus eragrostis & $A$ & exotic & 2.50 & 2.50 \\
\hline Cyperus gunnii & $A$ & native & 0.00 & 15.00 \\
\hline Cyperus lucidus & $A$ & native & 29.25 & 33.50 \\
\hline Dactylis glomerata & $\mathrm{D}$ & exotic & 2.50 & 0.00 \\
\hline Eleocharis sphacelata & $A$ & native & 38.64 & 53.91 \\
\hline Eucalyptus viminalis & $\mathrm{T}$ & native & 0.00 & 2.50 \\
\hline Galium aparine & $\mathrm{T}$ & exotic & 3.21 & 0.00 \\
\hline Galium leiocarpum & $\mathrm{T}$ & native & 2.50 & 2.50 \\
\hline Galium murale & $\mathrm{T}$ & exotic & 2.50 & 2.50 \\
\hline Geranium sp. & $\mathrm{T}$ & native & 2.50 & 3.64 \\
\hline Glyceria australis & $\mathrm{D}$ & native & 62.50 & 6.07 \\
\hline Glyceria maxima & $\mathrm{D}$ & exotic & 37.50 & 0.00 \\
\hline Gynatrix pulchella & $\mathrm{T}$ & native & 2.50 & 0.00 \\
\hline Helminthotheca echioides & $\mathrm{T}$ & exotic & 0.00 & 15.00 \\
\hline Holcus lanatus & $\mathrm{D}$ & exotic & 14.66 & 23.43 \\
\hline Hypochaeris radicata & $\mathrm{T}$ & exotic & 2.50 & 2.50 \\
\hline Hypolepis rugosula & $\mathrm{D}$ & native & 12.62 & 19.36 \\
\hline Hypericum tetrapterum & $\mathrm{D}$ & exotic & 5.91 & 9.52 \\
\hline Isolepis hookeriana & $A$ & native & 2.50 & 0.00 \\
\hline Isolepis inundata & $A$ & native & 4.17 & 6.07 \\
\hline Juncus articulatus & $\mathrm{D}$ & exotic & 0.00 & 2.50 \\
\hline Juncus bufonius & $\mathrm{D}$ & native & 2.50 & 0.00 \\
\hline Juncus pallidus & $\mathrm{D}$ & native & 2.50 & 0.00 \\
\hline Juncus planifolius & $\mathrm{D}$ & native & 2.50 & 0.00 \\
\hline Juncus procerus & $\mathrm{D}$ & native & 2.50 & 2.50 \\
\hline
\end{tabular}




\begin{tabular}{|c|c|c|c|c|}
\hline Juncus sp. & $\mathrm{D}$ & native & 5.63 & 5.63 \\
\hline Lachnagrostis filiformis & $\mathrm{D}$ & native & 0.00 & 3.16 \\
\hline Lemna disperma & $A$ & native & 2.50 & 2.50 \\
\hline Lotus uliginosus & $\mathrm{T}$ & exotic & 12.63 & 26.85 \\
\hline Lycopus australis & D & native & 6.88 & 13.82 \\
\hline Lythrum hyssopifolia & D & native & 0.00 & 2.50 \\
\hline Lythrum salicaria & $A$ & native & 2.50 & 0.00 \\
\hline Melaleuca sp. & D & native & 0.00 & 2.50 \\
\hline Microlaena stipoides & $\mathrm{T}$ & native & 2.50 & 8.75 \\
\hline Myriophyllum caput-medusae & $A$ & native & 2.50 & 2.50 \\
\hline Oxalis perennans & $\mathrm{T}$ & native & 2.50 & 2.50 \\
\hline Persicaria decipiens & $A$ & native & 7.50 & 11.11 \\
\hline Persicaria praetermissa & $A$ & native & 18.33 & 28.01 \\
\hline Persicaria subsessilis & $A$ & native & 2.50 & 5.63 \\
\hline Phalaris aquatica & D & exotic & 0.00 & 16.94 \\
\hline Phalaris arundinacea & $A$ & exotic & 8.80 & 6.67 \\
\hline Phragmites australis & $A$ & native & 4.71 & 14.58 \\
\hline Plantago lanceolata & $\mathrm{T}$ & exotic & 2.50 & 2.50 \\
\hline Poa annua & $\mathrm{T}$ & exotic & 2.50 & 0.00 \\
\hline Poa sieberiana & $\mathrm{T}$ & native & 17.50 & 5.00 \\
\hline Prunus sp. & $\mathrm{T}$ & exotic & 2.50 & 0.00 \\
\hline Prunella vulgaris & $\mathrm{D}$ & exotic & 0.00 & 2.50 \\
\hline Pteridium esculentum & $\mathrm{T}$ & native & 18.33 & 2.50 \\
\hline Ranunculus flammula & $A$ & exotic & 0.00 & 2.50 \\
\hline Ranunculus inundatus & $A$ & native & 2.50 & 2.50 \\
\hline Ranunculus repens & $A$ & exotic & 7.62 & 7.87 \\
\hline Rorripa palustris & D & exotic & 0.00 & 2.50 \\
\hline Rubus anglocandicans & $\mathrm{T}$ & exotic & 5.68 & 25.00 \\
\hline Rubus parvifolius & $\mathrm{T}$ & native & 2.50 & 7.86 \\
\hline Senecio linearifolius & $\mathrm{T}$ & native & 2.50 & 12.00 \\
\hline Senecio minimus & $\mathrm{T}$ & native & 2.50 & 4.29 \\
\hline Solanum nigrum & $\mathrm{T}$ & exotic & 10.83 & 6.67 \\
\hline Sonchus oleraceus & $\mathrm{T}$ & exotic & 2.50 & 2.50 \\
\hline Stellaria flaccida & $\mathrm{T}$ & native & 3.71 & 3.84 \\
\hline Stellaria media & $\mathrm{T}$ & exotic & 2.50 & 6.67 \\
\hline Tetrarrhena juncea & $\mathrm{T}$ & native & 2.50 & 4.58 \\
\hline Tradescantia fluminensis & $\mathrm{D}$ & exotic & 2.50 & 15.00 \\
\hline Trifolium repens & $T$ & exotic & 8.23 & 3.46 \\
\hline Triglochin procerum & $A$ & native & 15.00 & 2.50 \\
\hline
\end{tabular}


S2. Details of indicator species analyses results. See Fig. 3 for site codes. See S2 for full species names. Data and code for analyses available freely online at Open Science Framework: https://osf.io/TSY8U/

Association function: IndVal.g

Significance leve1 (alpha): 0.05

Total number of species: 79

Selected number of species: 42

Number of species associated to 1 group: 16

Number of species associated to 2 groups: 26

Number of species associated to 3 groups: 0

Number of species associated to 4 groups: 0

Number of species associated to 5 groups: 0

Number of species associated to 6 groups: 0

Number of species associated to 7 groups: 0

List of species associated to each combination:

Group MI-A \#sps. 6 stat p.value

$\begin{array}{llll}\text { LAC-FIL } & 0.935 & 0.005 * * \\ \text { PER-DEC } & 0.853 & 0.005 * * \\ \text { JUN-ART } & 0.707 & 0.005 * * \\ \text { ALT-DEN } & 0.612 & 0.015 * \\ \text { MEL-SP } & 0.612 & 0.010 * * \\ \text { ACA-SP } & 0.530 & 0.040 *\end{array}$

Group BC-A \#sps. 4 stat p.value

CAL-SEP $0.976 \quad 0.005 * *$

LYT-HYS $0.707 \quad 0.010 * *$

PHA-AQU $0.707 \quad 0.005 * *$

CRA-HEL $0.588 \quad 0.015$ *

Group WC-A \#sps. 2 stat p.value

SEN-LIN $0.667 \quad 0.010 * *$

RUB-PAR 0.5580 .015 *

Group MI-B \#sps. 2 stat p.value

$\begin{array}{lll}\text { MYR-CAP } & 0.722 & 0.01 * *\end{array}$

CAL-STA $0.577 \quad 0.02$ *

Group BC-B \#sps. 1 stat p.value

JUN-BUF $0.866 \quad 0.005 * *$

Group VC-B \#sps. 1 stat p.value

COP-QUA 0.5770 .025 *

Group MI-A+VC-A \#sps. 1 stat p.value

PER-PRA $0.6880 .005 * *$

Group MI-A+MI-B \#sps. 3 stat p.value

ELE-SPH $0.866 \quad 0.005 * *$

ISO-INU $0.788 \quad 0.005 * *$

CEN-COR $0.583 \quad 0.010 * *$

This article is protected by copyright. All rights reserved. 


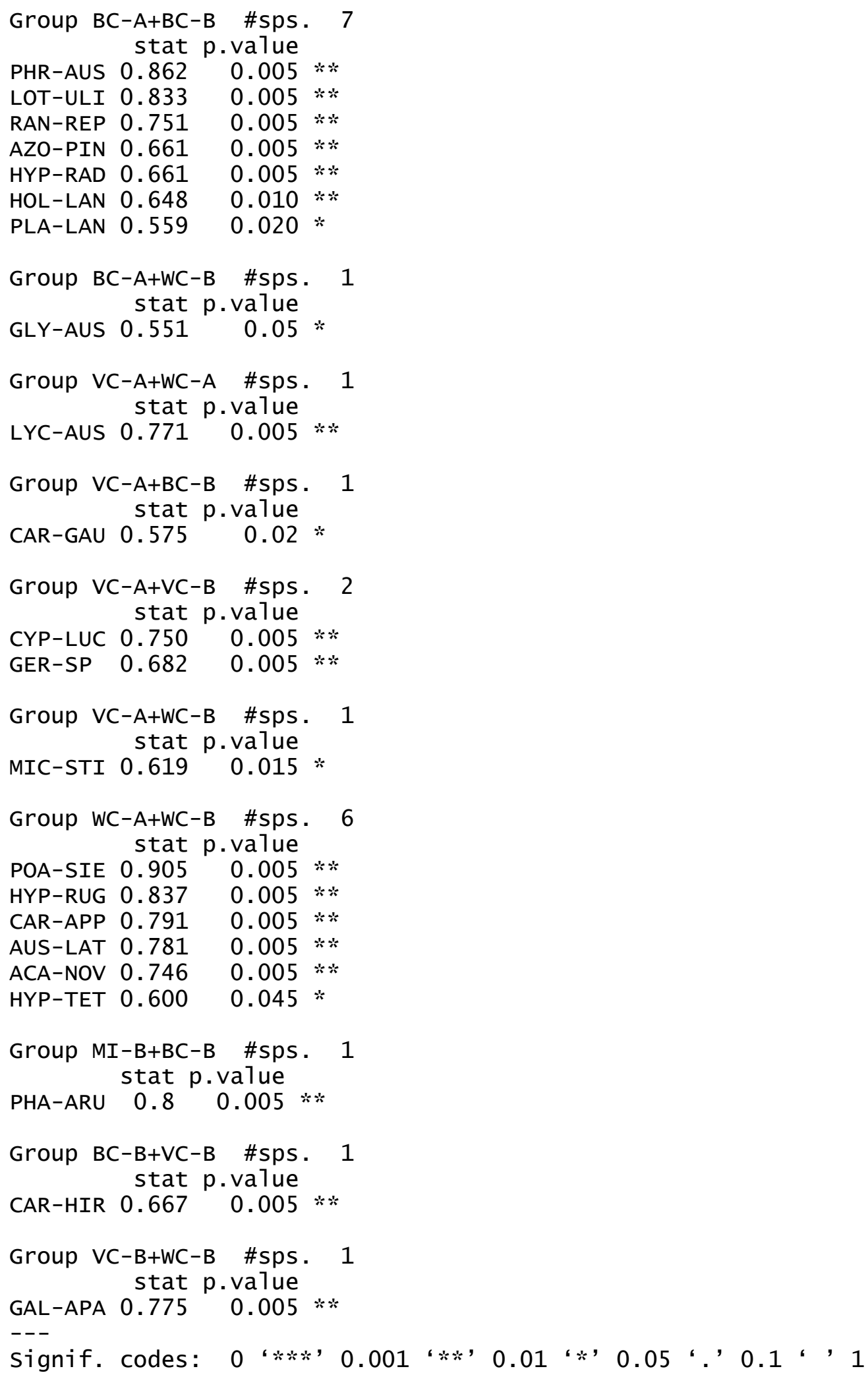




\section{University Library}

\section{- M M N E R VA A gateway to Melbourne's research publications}

Minerva Access is the Institutional Repository of The University of Melbourne

Author/s:

Duong, A;Greet, J;Walsh, CJ;Sammonds, MJ

Title:

Managed flooding can augment the benefits of natural flooding for native wetland vegetation

Date:

2019-01-01

Citation:

Duong, A., Greet, J., Walsh, C. J. \& Sammonds, M. J. (2019). Managed flooding can augment the benefits of natural flooding for native wetland vegetation. RESTORATION ECOLOGY, 27 (1), pp.38-45. https://doi.org/10.1111/rec.12816.

Persistent Link:

http://hdl.handle.net/11343/284013 